\title{
A single-centre experience of the implementation of adrenal vein sampling procedure: the impact on the diagnostic work-up in primary aldosteronism
}

\author{
Jacek Kądziela ${ }^{1}$, Aleksander Prejbisz ${ }^{2}$, Ilona Michałowska ${ }^{3}$, Sylwia Kołodziejczyk-Kruk², \\ Leo Schultze Kool ${ }^{4}$, Marek Kabat ${ }^{2}$, Hanna Janaszek-Sitkowska², Sadegh Toutounchi' ${ }^{5}$, \\ Zbigniew Gałązka ${ }^{5}$, Urszula Ambroziak ${ }^{6}$, Tomasz Bednarczuk ${ }^{6}$, Dorota Ptasińska-Wnuk \\ Michał Hoffmann ${ }^{8}$, Magdalena Januszewicz ${ }^{9}$, Andrzej Januszewicz ${ }^{2}$, Adam Witkowski ${ }^{1}$ \\ 'Department of Invasive Cardiology and Angiology, Institute of Cardiology, Warsaw, Poland \\ ${ }^{2}$ Department of Hypertension, Institute of Cardiology, Warsaw, Poland \\ ${ }^{3}$ Department of Radiology, Institute of Cardiology, Warsaw, Poland \\ ${ }^{4}$ Department of Radiology, Radboud University Medical Centre, Nijmegen, Netherlands \\ ${ }^{5}$ Department of General and Endocrine Surgery, Medical University of Warsaw, Warsaw, Poland \\ ${ }^{6}$ Department of Internal Medicine and Endocrinology, Medical University of Warsaw, Warsaw, Poland \\ ${ }^{7}$ Clinic of Endocrinology, University Hospital WAM-CSW, Lodz, Poland \\ ${ }^{8}$ Department of Hypertension and Diabetology, Medical University of Gdansk, Gdansk, Poland \\ ${ }^{9} 2^{\text {nd }}$ Department of Clinical Radiology, Medical University of Warsaw, Warsaw, Poland
}

\begin{abstract}
A bstract
Background: Primary aldosteronism is one of the most common causes of secondary hypertension. Adrenal vein sampling (AVS) remains a "gold standard" procedure in differentiation between unilateral (adenoma) and bilateral (hyperplasia) disease. Aim: The aim of this study was to present our single-centre experience in establishing and implementating the AVS procedure. Methods: All patients had primary aldosteronism confirmed in a salt-infusion test. AVS was performed sequentially during a continuous intravenous infusion of cosyntropin and was preceded by multislice contrast-enhanced computed tomography (CT) examination of adrenal glands performed a few weeks before AVS in the majority of patients. AVS was regarded as successful if the ratio of each adrenal vein cortisol to inferior vena cava cortisol levels (selectivity index [SI]) was higher than 3.0. In the case of failure, a second attempt was considered in a few weeks. Patients were divided into four groups according to the order of the procedure by quartiles.

Results: Between 31 May, 2012 and 5 May, 2016, AVS was performed in 124 patients (69\% males, aged $55.3 \pm 10.3$ years) and was successful in 120 (96.8\%) patients. All failed cases were due to the failure of cannulation of the right adrenal vein. The first-attempt success rate was $94.3 \%$ (117 of 124 patients) and increased from $83.9 \%$ in the first 31 patients to $100 \%$ in the last 31 patients. Similarly, the overall success rate increased from $93.5 \%$ to $100 \%$. The right SI was significantly higher than the left one (26.4 vs. 11.0, $\mathrm{p}<0.0001)$. Both indices did not differ across quartiles of patients. No complications occurred during the procedure.

Conclusions: The AVS procedure, preceded by adrenal CT, may be implemented into daily diagnostic practice safely with an excellent success rate.
\end{abstract}

Key words: adrenal vein sampling, primary aldosteronism, secondary hypertension

Kardiol Pol 2017; 75, 1: 28-34

\section{Address for correspondence:}

Jacek Kądziela, MD, PhD, Department of Invasive Cardiology and Angiology, Institute of Cardiology, ul. Alpejska 42, 04-628 Warszawa, Poland, tel: +48 22 3434342 , fax: +48223434506, e-mail: kadziela@ikard.pl

Received: 12.07.2016 Accepted: 06.10.2016 Available as AoP: 17.11.2016

Kardiologia Polska Copyright (C) Polskie Towarzystwo Kardiologiczne 2017 


\section{INTRODUCTION}

Primary aldosteronism (PA) remains one of the most common causes of secondary hypertension, with a prevalence between $4.6 \%$ and $18 \%$ [1-3]. In patients with resistant hypertension, the prevalence of PA is even higher, ranging from $17 \%$ to $23 \%$ [4-6]. The vast majority of cases are caused by aldosterone-producing adenomas or bilateral adrenal hyperplasia [7]. Other potential causes such as adenocarcinoma are very rare. The differentiation between unilateral and bilateral disease is essential for diagnosis confirmation and proper treatment. Patients with bilateral hyperplasia are treated with a mineralocorticoid receptor antagonist, whereas the subjects with a unilateral adenoma undergo adrenalectomy [8, 9]. Because aldosterone-producing microadenomas and multiple bilateral lesions are often undetectable on computed tomography (CT), there is a substantial risk of misdiagnosis when using only $\mathrm{CT}$ scanning [10-16]. The current guidelines on the management of PA recommend adrenal vein sampling (AVS) as a "gold standard" procedure to differentiate between both subtypes in the majority of patients with PA [15].

However, AVS is a challenging procedure, mainly because of the difficulty in cannulating the right adrenal vein (RAV). The RAV is a very small vessel with varying anatomical drainage directly into the large inferior caval vein. Even in experienced hands, the efficacy of the procedure in referral centres rarely exceeds $90 \%[15,17]$. We present our single-centre experience in establishing and implementating the AVS procedure based on the Polish-Dutch collaboration.

\section{METHODS}

The project aimed at implementation of AVS consisted of a few consecutive relevant steps under the coordination by the Department of Hypertension. Firstly, one dedicated interventional cardiologist (J.K.) underwent training in the Radboud University Medical Centre, Nijmegen, the Netherlands - a centre with expertise in AVS. He performed several cases under the supervision of an experienced interventional radiologist (L.S.K.) and reviewed more than 50 previous angiographies of adrenal veins. Secondly, multislice contrast-enhanced CT examination of adrenal glands performed a few weeks before AVS was obligatory in the first 30 patients. Adrenal CT was done according to the pre-specified protocol, using a dual-source, 128-slice CT scanner (Somatom Flash, Siemens, Germany). The following scanning parameters were applied: beam collimation $64 \times 0.6 \mathrm{~mm}, 128$ slices, gantry rotation time $0.28 \mathrm{~s}$, tube voltage $80-140 \mathrm{kV}$, and slice thickness $1 \mathrm{~mm}$. The scan parameters were optimised for body size. Contrast-enhanced scans were obtained in arterial and venous phases after intravenous administration of 80-100 mL of highly iodinated contrast material $(\geq 350 \mathrm{mg} / \mathrm{mL}$ ), injected at a rate of $5 \mathrm{~mL} / \mathrm{s}$ via antecubital vein and during breath-holding. $1.0 \mathrm{~mm}$ slices were reconstructed for adrenal vein visualisation (Fig. 1).

After completion of the first 30 procedures, CT scans with good quality images that had been previously performed in referring hospitals were also accepted. In two patients from the first group with a history of the contrast-medium allergy, magnetic resonance scans were obtained instead of CT before AVS. All images were evaluated in terms of adrenal vein topography by one experienced radiologist (I.M.) together with an interventional cardiologist responsible for AVS. After completion of 50 procedures with good success rate, in cases of CT unavailability, the first attempt of the procedure was also allowable without preprocedural CT scans. Nevertheless, all those patients underwent routine adrenal CT imaging later, for adrenal glands assessment and adrenocarcinoma exclusion.

Thirdly, the local laboratory was equipped with a rapid cortisol assay, providing preliminary results (plasma cortisol concentrations) within $60 \mathrm{~min}$ and confirming correct adrenal vein cannulation.

\section{Diagnostic algorithm of PA}

Before qualification for AVS, all patients referred to our institution for suspicion of PA were hospitalised in the Department of Hypertension and underwent a three-stage diagnostic

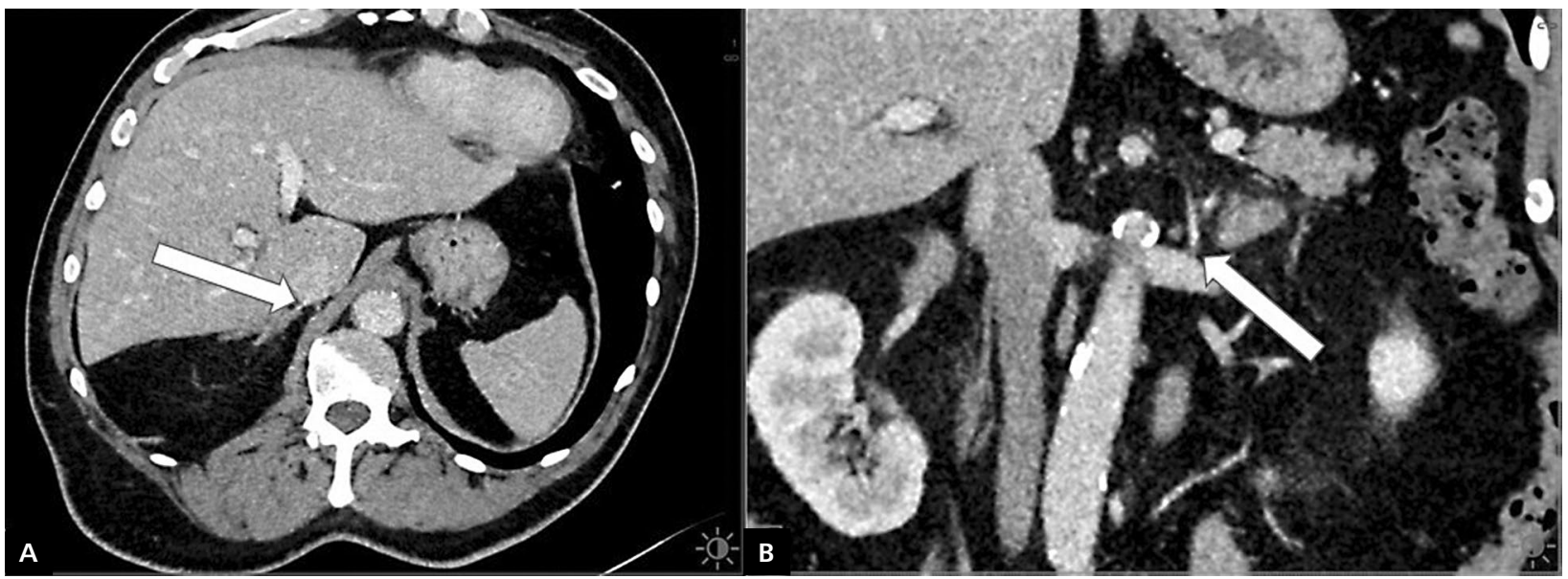

Figure 1. Adrenal multislice contrast-enhanced computed tomography visualisation of the right (A) and left (B) adrenal vein (white arrows) 


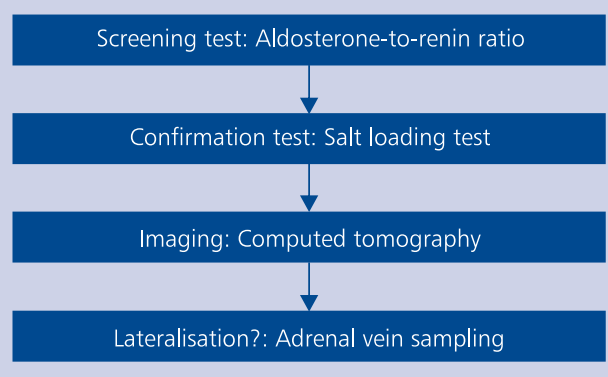

Figure 2. Diagnostic algorithm in primary aldosteronism

algorithm according to the Endocrine Society Clinical Practice Guidelines, as presented in Figure 2 [15]. Patients in whom the plasma aldosterone to renin ratio was higher than $30 \mathrm{ng} / \mathrm{dL}$ and serum aldosterone was higher than $15 \mathrm{ng} / \mathrm{dL}$ underwent a saline infusion test (intravenous infusion of $2 \mathrm{~L}$ of $0.9 \%$ saline for $4 \mathrm{~h}$ ). Post-infusion plasma aldosterone level $>10 \mathrm{ng} / \mathrm{dL}$ confirmed a diagnosis of PA. Then an imaging test (predominantly $\mathrm{CT}$ ) was performed for visualisation of adrenal glands and veins.

\section{Adrenal vein sampling}

Adrenal vein sampling was performed after correction of hypokalaemia and modification of antihypertensive therapy according to the 2008 Endocrine Society Guidelines [18]. A continuous intravenous infusion of cosyntropin, a synthetic adrenal cortical stimulating hormone $(50 \mu \mathrm{g} / \mathrm{h})$, was started at least $60 \mathrm{~min}$ before the procedure.

All procedures were done at the Cardiac Catheterisation Laboratory of the Department of Interventional Cardiology and Angiology by one interventional cardiologist skilled in coronary and peripheral endovascular techniques. During local anaesthesia, a $5 \mathrm{Fr}$ sheath was inserted into the right femoral vein. According to the protocol, the operator started each procedure with the cannulation of the RAV. A C2 or C1 catheter or Simmons-Sidewinder 2 was used for RAV catheterisation. Left adrenal vein (LAV) was cannulated with Simmons-Sidewinder 2 or 3 catheter or Judkins Right 3.5 catheter, as presented in Figure 3. AVS was performed sequentially with two separate $5-\mathrm{mL}$ blood samples from each adrenal vein, and a reference blood sample from the inferior vena cava (IVC) was drawn for cortisol and aldosterone measurements. Then the right and left selectivity index (SI) was calculated as the ratio of each adrenal vein cortisol to IVC cortisol levels. AVS was regarded as successful if the SIs were higher than 3.0. In the case of failure, a second attempt was considered in a few weeks.

\section{Statistical analysis}

Patients were divided into four groups according to the order of the procedure by quartiles: group 1 consisted of the first 31 patients (patient number 1-31); group 2, patients 32-62; group 3, 63-93; and group 4, 94-124. Statistical analysis was performed with MedCalc Statistical Software version

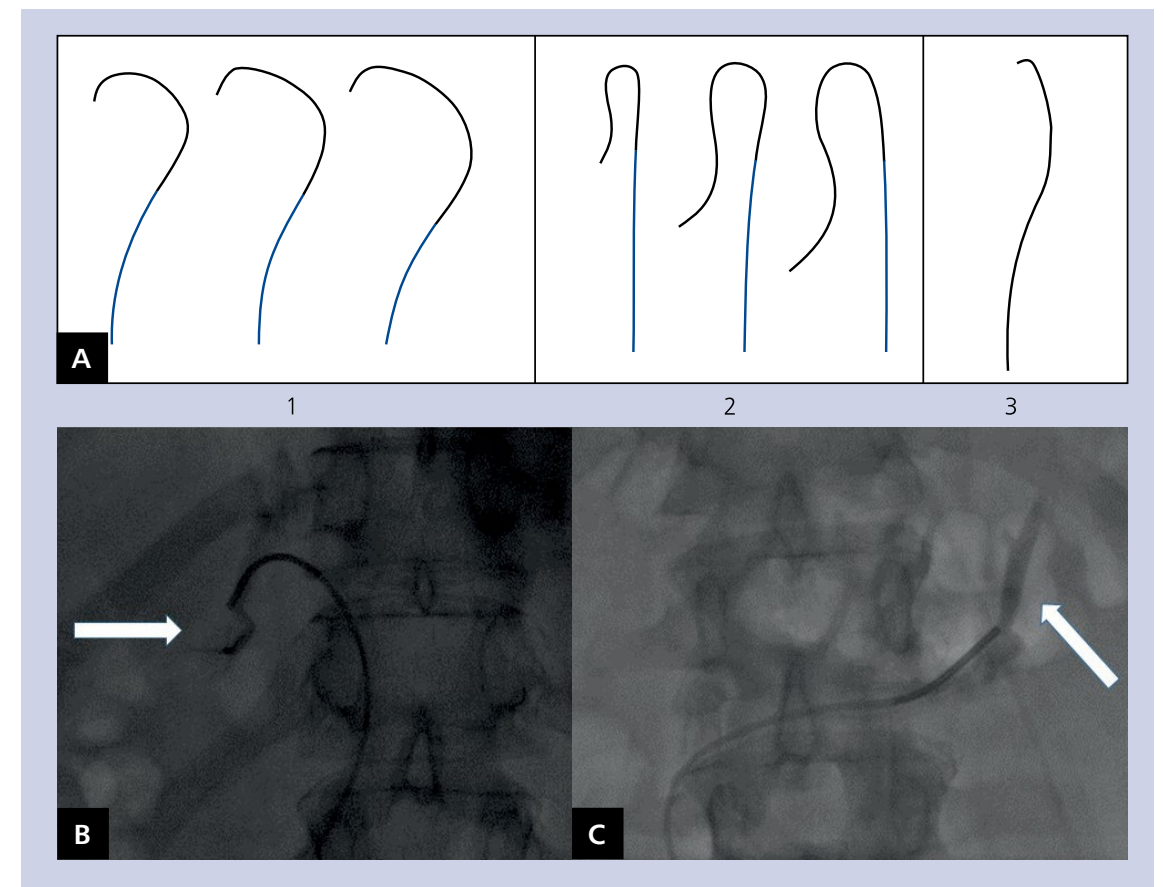

Figure 3. Adrenal vein sampling; A. Catheters used (1 - Cobra, 2 - Simmons-Sidewinder, 3 - Judkins right); B. Right adrenal vein (white arrow); C. Left adrenal vein (white arrow) 


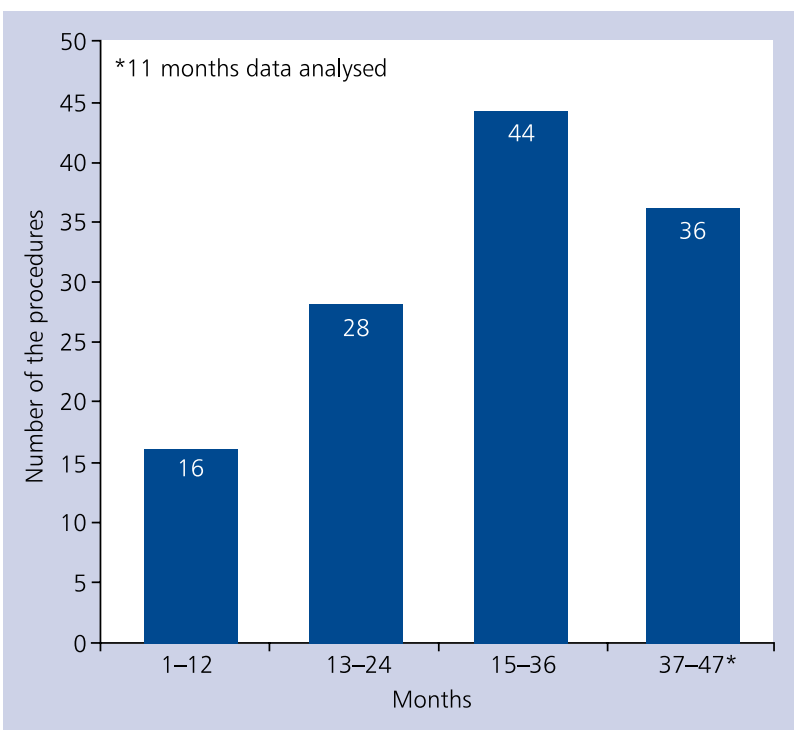

Figure 4. The number of adrenal vein sampling procedures

16.4.3 (MedCalc Software bvba, Ostend, Belgium; https:// www.medcalc.org; 2016). Differences in continuous variables were compared using Wilcoxon test or analysis of variance. Data are presented as medians and interquartile ranges (IQR) given in brackets. The age is presented as mean and standard deviation. A p value less than 0.05 was considered statistically significant.

\section{RESULTS}

Between 31 May, 2012 and 5 May, 2016, AVS was performed in 124 patients ( $69 \%$ males, aged $55.3 \pm 10.3$ years). The number of procedures had been growing for each full 12-month period, as presented in Figure 4.

The procedure was successful in 120 patients - the overall success rate was $96.8 \%$. All failed cases were due to failure of the cannulation of the RAV, as reflected by a low right-sided SI. The first attempt success rate was $94.3 \%$ (117 of 124 patients). The second attempt was undertaken in five patients, being successful in three. Interestingly, in one of these cases RAV was found but was non-coaxially cannulated with a 5-French $\mathrm{C} 2$ catheter at the first attempt, and the operator was not able to aspirate blood. At the second attempt, a smaller diameter 4-French catheter was used, which facilitated deeper coaxial intubation and blood drawing. Two other patients were unselective during repeat AVS despite high quality CT images showing the ostium of RAV. In the two remaining failed cases the RAV was not clearly visible in CT with the suspicion of draining into the hepatic vein instead of IVC in one case. Moreover, one of them previously underwent unsuccessful AVS in another clinical centre, so the second attempt was not made in either patient.

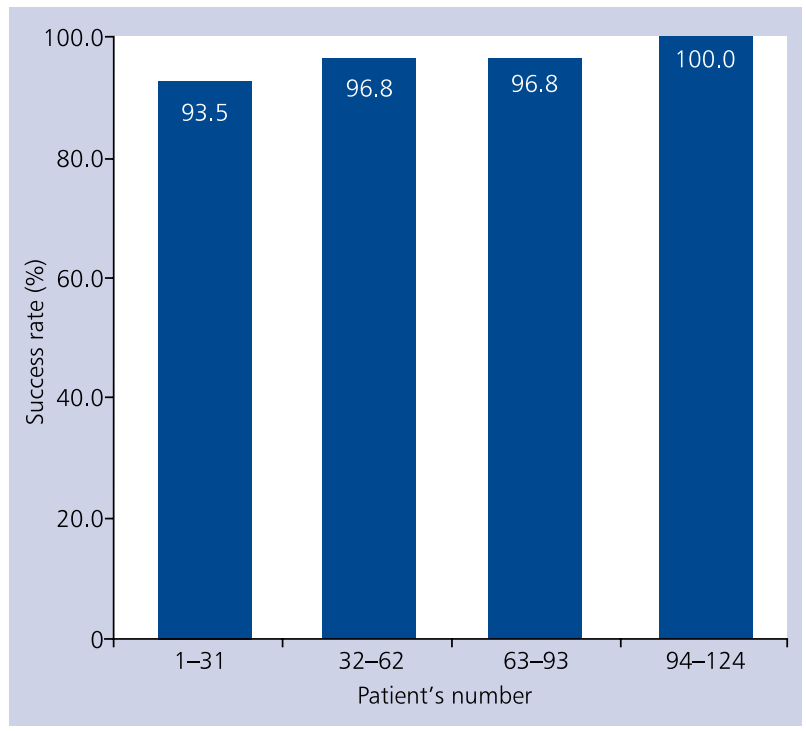

Figure 5. Technical success rate in relation to the learning curve

\section{The learning curve}

The procedure was performed successfully at the first attempt in 12 of 15 first patients (80\%). The success rate of the first attempt increased from $83.9 \%$ in group 1 to $100 \%$ in group 4 . Similarly, the overall success rate increased from $93.5 \%$ to $100 \%$ across the groups, as presented in Figure 5.

The CT scans were available and evaluated in 100\%, $96.8 \%, 74.2 \%$, and $83.9 \%$ patients from groups $1-4$, respectively. The percentage of CT scans done in referring hospitals and accepted for the evaluation was $0 \%, 36.7 \%, 30.4 \%$, and $35.5 \%$ across the groups. The overall success rate of AVS was 96.3\% when the procedure was based on CT images obtained within the Institute of Cardiology, 96.5\% in patients based on CT performed outside of the Institute of Cardiology, and $100 \%$ in patients without any imaging available before the procedure. No complications occurred during the procedure.

\section{The technique of the procedure}

The RAV was successfully cannulated with the Cobra 2 catheter in 115 (95.8\%) patients, with Sim-2 catheter in four $(3.3 \%)$, and Cobra $1(0.9 \%)$ in one patient. The LAV was catheterised using a Sim-2 catheter in 105 (87.5\%) patients, Sim-3 in eight (6.7\%), and JR 3.5 in seven (5.8\%) subjects.

The right SI was significantly higher than the left one (26.4 [IQR:18.2-33.7] vs. 11.0 [IQR: 6.0-14.1], p < 0.0001). Both indices did not differ across groups 1-4 (consecutively, right: 23.0 vs. 28.0 vs. 25.4 vs. $24.8, p=N S$ and left: 12.8 vs. 11.2 vs. 9.4 vs. 9.7, $p=N S$ ). The left SI was non-significantly higher when the LAV was cannulated using a JR 3.5 catheter (16.3 [IQR: 10.4-20.5]) or Sim-3 catheter (13.0 [IQR: 10.5-17.1]) as compared to a Sim-2 catheter 
(10.3 [IQR: 8.0-13.9], $\mathrm{p}=\mathrm{NS}$ ). The right SI was not related to the type of catheter used during the procedure (data not shown).

\section{DISCUSSION}

We present our single-centre experience in establishing and implementing an AVS procedure as a final diagnostic tool in patients with PA. Few substantial issues contributed to the success of the whole project and excellent procedure results. First of all, one dedicated interventional cardiologist performed all procedures after appropriate training in a highly experienced Dutch centre. His former experience in other endovascular techniques and useful training with the possibility for review of more than 50 adrenal venographies significantly shortened the learning curve. Our results demonstrate that in experienced hands, after completion of 30 procedures, an excellent success rate may be achieved. Secondly, obligatory locally performed, high quality $\mathrm{CT}$ adrenal CT-scans with visualisation of adrenal veins, evaluated by one experience radiologist together with an interventional cardiologist, substantially facilitated the procedure. We also demonstrated that after 30 procedures, lower quality CT images also might be acceptable for RAV evaluation. After completion of 50-60 procedures, in very experienced centres, the first attempt may be done without CT scans, if unavailable. Nevertheless, it should be emphasised that CT imaging is necessary in all PA patients, not only by facilitating the AVS, but also enabling aldosterone-producing adenocarcinoma detection.

The overall success rate was over $95 \%$ and had been increasing with the procedures order, achieving even 100\% in the last 30 patients. Paradoxically, probably by chance, the success rate of the patients without preprocedural CT was even higher (100\%) than when CT was evaluated before the procedure. Obviously it should be mentioned that the procedures without CT were acceptable only in the latter phase of the project, after accomplishment of the learning curve and the highest level of experience achievement. Moreover, it should be interpreted with caution because of small number of patients done without preprocedural CT.

The crucial role of the learning curve and growing experience in achievement of excellent results has also been demonstrated in other published reports $[15,19,20]$. As AVS still remains a demanding procedure, few studies have proposed various techniques enabling stable catheter position during blood sampling, like wire insertion or abdominal pressure manoeuvre [21-23].

The number of procedures was relatively small within the first year and then grew significantly in the following years. It reflects the substantial efforts that had to be made by the Department of Hypertension in coordinating the project, by informing other centres about the available diagnostic tool. The creation of the network of cooperating hospitals led to increased numbers of the procedures within the following years.
The level of SI was not related to the type of catheter used, nor to the order of the procedure. As expected, the SI was significantly lower on the left side, which results from the LAV anatomy that joins the inferior phrenic vein forming a common trunk where the catheter is usually placed and aspirates diluted blood. Previous reports indicated that selective cannulation of the LAV does not provide additional benefit [24, 25]. The selectivity indices were remarkably high because all procedures were performed during cosyntropin infusion. Several previous reports demonstrated increased selectivity and efficacy of the procedure achieved by cosyntropin administration [26-28]. In some other centres, AVS is performed simultaneously. In our study we demonstrated that successive unilateral sampling is as good as bilateral simultaneous sampling. The reference blood sample was drawn from the distal part of IVC (above the bifurcation); however, it can also be taken from a sheath placed in the femoral vein.

\section{CONCLUSIONS}

In summary, we present our single-centre experience with implementation of AVS into daily clinical practice. Our results also corroborate the observations of other centres and indicate that when performed by an experienced specialist, AVS appears to be a safe. Thanks to the excellent cooperation between the hypertension unit, a dedicated radiologist, and the interventional cardiologist performing the procedure, with the support of a cooperating Dutch centre in the initial phase of the project, we were able to obtain outstanding results and implement AVS into the routine diagnostic scheme of patients with primary aldosteronism.

\section{Acknowledgements}

We would like to express our very great appreciation to Professor Jacques Lenders for his valuable and comprehensive review of the manuscript and to Doctor Jaap Deinum and Tanja Dekkers for their excellent cooperation.

This study was supported by the scientific project of The Institute of Cardiology, Warsaw, Poland, No. 2.13/VII/12.

\section{Conflict of interest: none declared}

\section{References}

1. Stowasser M, Gordon RD, Gunasekera TG et al. High rate of detection of primary aldosteronism, including surgically treatable forms, after 'nonselective' screening of hypertensive patients. J Hypertension, 2003; 21: 2149-2157. doi: 10.1097/00004872-200311000-00025.

2. Mulatero P, Stowasser M, Loh KC et al. Increased diagnosis of primary aldosteronism, including surgically correctable forms, in centers from five continents. J Clin Endocrinol Metab, 2004; 89: 1045-1050. doi: 10.1210/jc.2003-031337.

3. Rossi GP, Bernini G, Desideri G et al. Renal damage in primary aldosteronism: results of the PAPY Study. Hypertension, 2006; 48: 232-238. doi: 10.1161/01.HYP.0000230444.01215.6a.

4. Calhoun DA. Is there an unrecognized epidemic of primary aldosteronism? Pro Hypertension, 2007; 50: 447-453. doi: 10.1161/HYPERTENSIONAHA.106.086116. 
5. Stowasser M, Taylor PJ, Pimenta E et al. Laboratory investigation of primary aldosteronism. Clinical Biochemist. Reviews, 2010;31:39-56.

6. Florczak E, Prejbisz A, Szwench-Pietrasz E et al. Clinical characteristics of patients with resistant hypertension: the RESIST-POL study. J Hum Hypertens, 2013; 27: 678-685. doi: 10.1038/jhh.2013.32.

7. Young WF. Young. Primary aldosteronism: renaissance of a syndrome. Clin Endocrinol, 2007; 66: 607-618.

8. Catena C, Colussi G, Sechi LA. Treatment of primary aldosteronism and organ protection. Int J Endocrinol, 2015; 2015: 597247. doi: 10.1155/2015/597247.

9. Muth A, Ragnarsson O, Johannsson $\mathrm{G}$ et al. Systematic review of surgery and outcomes in patients with primary aldosteronism. Br J Surg, 2015; 102: 307-317. doi: 10.1002/bjs.9744.

10. Kempers MJ, Lenders JW, van Outheusden L et al. Systematic review: diagnostic procedures to differentiate unilateral from bilateral adrenal abnormality in primary aldosteronism. Ann Intern Med, 2009; 151: 329-337.

11. Diederich S, Bidlingsmaier M, Quinkler M et al. Diagnostik des primären Hyperaldosteronismus. Med Klinik, 2007; 102: 16-21.

12. Schirpenbach C, Segmiller F, Diederich S et al. The diagnosis and treatment of primary hyperaldosteronism in Germany — results on 555 patients from the German Conn Registry. Dtsch Arztbl Int, 2009; 106: 305-311.

13. Rossi GP, Auchus RJ, Brown M et al. An expert consensus statement on use of adrenal vein sampling for the subtyping of primary aldosteronism. Hypertension, 2014; 63: 151-160.

14. Dekkers T, Prejbisz A, Kool LJ et al. Adrenal vein sampling versus CT scan to determine treatment in primary aldosteronism: an outcome-based randomised diagnostic trial.Lancet Diabetes Endocrinol, 2016; doi: 10.1016/S2213-8587(16)30100-0. [Epub ahead of print].

15. Funder JW, Carey RM, Mantero F et al. The management of primary aldosteronism: case detection, diagnosis, and treatment: an Endocrine Society Clinical Practice Guideline. J Clin Endocrinol Metab, 2016; 101: 1889-1916. doi: 10.1210/jc.2015-4061.

16. Bednarczuk T, Bolanowski M, Sworczak K et al. Adrenal incidentaloma in adults - management recommendations by the Polish Society of Endocrinology. Endokrynol Pol, 2016; 67: 234-258. doi: 10.5603/EP.a2016.0039.

17. Trerotola SO, Asmar M, Yan Y et al. Failure mode analysis in adrenal vein sampling: a single-center experience. J Vasc Interv Radiol, 2014; 25: 1611-1619. doi: 10.1016/j.jvir.2014.06.029.
18. Funder JW, Carey RM, Fardella C et al.; Endocrine Society. Case detection, diagnosis, and treatment of patients with primary aldosteronism: an endocrine society clinical practice guideline. J Clin Endocrinol Metab, 2008; 93: 3266-3281. doi: 10.1210/jc.2008-0104.

19. Siracuse JJ, Gill HL, Epelboym I et al. The vascular surgeon's experience with adrenal venous sampling for the diagnosis of primary hyperaldosteronism. Ann Vasc Surg, 2014; 28: 1266-1270. doi: 10.1016/j.avsg.2013.10.009.

20. Wachtel H, Zaheer S, Shah PK et al. Role of adrenal vein sampling in primary aldosteronism: Impact of imaging, localization, and age. J Surg Oncol, 2016; 113: 532-537. doi: 10.1002/jso.24182.

21. Andrews JC, Thompson SM, Young WF. A coaxial guide wire-catheter technique to facilitate right adrenal vein sampling: evaluation in 76 patients. J Vasc Interv Radiol, 2015; 26 : 1871-1873. doi: 10.1016/j.jvir.2015.08.020.

22. Kaitoukov Y, Soulez G, Oliva VL et al. Coaxial guide wire placement in the right adrenal vein for repeated adrenal venous samplings.Cardiovasc Intervent Radiol, 2014; 37: 795-799. doi: 10.1007/s00270-013-0794-9.

23. Araki T, Okada H, Araki T. Abdominal pressing maneuver during adrenal venous sampling for stabilization of catheter position. Cardiovasc Intervent Radiol, 2014; 37: 498-501. doi: 10.1007/s00270-013-0749-1.

24. Takada A, Suzuki K, Mori Y et al. Comparison of the central adrenal vein and the common trunk of the left adrenal vein for adrenal venous sampling. J Vasc Interv Radiol, 2013; 24: 550-557. doi: 10.1016/j.jvir.2013.01.007.

25. Umakoshi H, Wada N, Ichijo T et al.; WAVES-J Study Group. Optimum position of left adrenal vein sampling for subtype diagnosis in primary aldosteronism. Clin Endocrinol (Oxf), 2015; 83: 768-773. doi: 10.1111/cen.12847.

26. Monticone S, Satoh F, Giacchetti G et al. Effect of adrenocorticotropic hormone stimulation during adrenal vein sampling in primary aldosteronism. Hypertension, 2012; 59: 840-846. doi: 10.1161/HYPERTENSIONAHA.111.189548.

27. Elliott P, Holmes DT. Adrenal vein sampling: substantial need for technical improvement at regional referral centres. Clin Biochem, 2013; 46: 1399-1404. doi: 10.1016/j.clinbiochem.2013.04.004.

28. Wolley MJ, Ahmed AH, Gordon RD et al. Does ACTH improve the diagnostic performance of adrenal vein sampling for subtyping primary aldosteronism? Clin Endocrinol (Oxf), 2016; doi: 10.1111/cen.13110

Cite this article as: Kądziela J, Prejbisz A, Michałowska I et al. A single-centre experience of the implementation of adrenal vein sampling procedure: the impact on the diagnostic work-up in primary aldosteronism. Kardiol Pol, 2017; 75: 28-34. doi: 10.5603/KP.a2016.0166. 


\title{
Wprowadzenie cewnikowania żył nadnerczowych do schematu postępowania diagnostycznego u pacjentów z pierwotnym hiperaldosteronizmem: doświadczenie ośrodka
}

\author{
Jacek Kądziela ${ }^{1}$, Aleksander Prejbisz², Ilona Michałowska ${ }^{3}$, Sylwia Kołodziejczyk-Kruk², \\ Leo Schultze Kool ${ }^{4}$, Marek Kabat ${ }^{2}$, Hanna Janaszek-Sitkowska², Sadegh Toutounchi' ${ }^{5}$, \\ Zbigniew Gałązka ${ }^{5}$, Urszula Ambroziak ${ }^{6}$, Tomasz Bednarczuk ${ }^{6}$, Dorota Ptasińska-Wnuk ${ }^{7}$, \\ Michał Hoffmann ${ }^{8}$, Magdalena Januszewicz ${ }^{9}$, Andrzej Januszewicz ${ }^{2}$, Adam Witkowski ${ }^{1}$ \\ ${ }^{1}$ Klinika Kardiologii Interwencyjnej i Angiologii, Instytut Kardiologii, Warszawa \\ ${ }^{2}$ Klinika Nadciśnienia Tętniczego, Instytut Kardiologii, Warszawa \\ ${ }^{3}$ Klinika Radiologii, Instytut Kardiologii, Warszawa \\ ${ }^{4}$ Department of Radiology, Radboud University Medical Centre, Nijmegen, Holandia \\ ${ }^{5}$ Klinika Chirurgii Ogólnej i Endokrynologicznej, Warszawski Uniwersytet Medyczny, Warszawa \\ ${ }^{6}$ Klinika Chorób Wewnętrznych i Endokrynologii, Warszawski Uniwersytet Medyczny, Warszawa \\ ${ }^{7}$ Klinika Endokrynologii, Szpital Uniwersytecki WAM-CSW, Łódź \\ ${ }^{8}$ Klinika Nadciśnienia Tętniczego i Diabetologii, Gdański Uniwerystet Medyczny, Gdańsk \\ 9|l Zakład Radiologii Klinicznej, Warszawski Uniwersytet Medyczny, Warszawa
}

\section{Streszczenie}

Wstęp: Pierwotny hiperaldosteronizm jest jedną z najczęstszych przyczyn wtórnego nadciśnienia tętniczego. Cewnikowanie żył nadnerczowych (AVS) pozostaje metodą referencyjną w rozróżnieniu między jednostronną (gruczolak) a obustronną (przerost guzkowy) postacią choroby.

Cel: Celem niniejszej pracy było zaprezentowanie jednoośrodkowych wyników we wprowadzeniu tej procedury do praktyki klinicznej.

Metody: U wszystkich pacjentów potwierdzono pierwotny hiperaldosteronizm w teście obciążenia solą. AVS wykonywano sekwencyjnie w trakcie ciągłej dożylnej infuzji syntetycznej kortykotropiny (ACTH) i poprzedzano u większości pacjentów tomografią komputerową (CT) nadnerczy kilka tygodni przed cewnikowaniem. AVS zdefiniowano jako skuteczne, jeśli stężenie kortyzolu w żyle nadnerczowej było 3-krotnie wyższe niż w żyle głównej dolnej (współczynnik selektywności > 3.0). Pacjenci zostali podzieleni na 4 kwartyle wg kolejności wykonania cewnikowania. W przypadku niepowodzenia rozważano indywidualnie drugą próbę cewnikowania po kilku tygodniach.

Wyniki: Pomiędzy 31 maja 2012 r. a 5 maja 2016 r. wykonano AVS u 124 pacjentów (69\% mężczyzn w wieku 55,3 \pm 10,3 roku). Badanie było skuteczne u 120 (96,8\%) osób. Przyczyną wszystkich nieskutecznych procedur było niepowodzenie kaniulacji prawej żyły nadnerczowej. Odsetek skutecznych procedur w pierwszej próbie cewnikowania wyniósł 94,3\% (117 z 124 chorych) i zwiększał się z 83,9\% u pierwszych 31 pacjentów do 100\% u ostatnich 31 chorych. Podobnie, całkowita skuteczność wzrosła odpowiednio z 93,5\% do 100\%. Współczynnik selektywności był wyższy po stronie prawej niż lewej (26,4 vs. 11,0; p < 0,0001), oba współczynniki nie zmieniały się w poszczególnych kwartylach pacjentów. Nie wystąpiły żadne powikłania związane z procedurą cewnikowania.

Wnioski: Cewnikowanie żył nadnerczowych, poprzedzone badaniem CT nadnerczy, jest procedurą bezpieczną, możliwą do wprowadzenia do praktyki klinicznej z wysokim odsetkiem skuteczności.

Słowa kluczowe: cewnikowanie żył nadnerczowych, pierwotny hiperaldosteronizm, wtórne nadciśnienie tętnicze

Kardiol Pol 2017; 75, 1: 28-34 